MOVERS

\author{
John Polich, director, Global NeuroLab \\ Operations, NeuroFocus, Berkeley, California
}

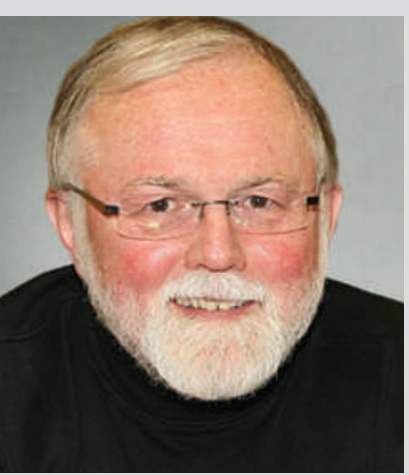

1996-2009: Associate tenured professor, molecular and integrative neurosciences department, Scripps Research Institute, La Jolla, California 1994-2009: Adjunct professor, psychology department, University of California, San Diego, La Jolla, California

John Polich learned to drive a tractor on his family's lowa farm, but he had little interest in farming. Looking at the field's lone cottonwood tree, he was more intrigued with how his brain deciphered that the object was a tree, or that it was green. Polich spent the next 30 years in academia as a cognitive neuroscientist studying memory and the brain's response to disease and addiction. Now, with a late career move into industry at NeuroFocus, he hopes to make use of the brain-wave activity techniques he's helped to develop.

Polich's propensity for contemplation led him to a Benedictine seminary in Conception, Missouri, for college. But after two years, he decided he wasn't monk material. He transferred to the University of lowa, where he majored in experimental psychology. "I wanted to understand how the brain produced cognition," he says. In just eight months, he completed a master's degree in cognitive psychology at Wayne State University, Michigan.

As one of the first PhD candidates in cognitive psychology at Dartmouth College, New Hampshire, Polich did some of the earliest recording of brain waves. He later did a postdoc at the University of Illinois with Emanuel Donchin, a leader in the use of specific brain-wave signals to assess attention and memory.

Keen to deal with patients, he built his own lab at the Scripps Research Institute in La Jolla to study patients in the early stages of Alzheimer's disease. But, as he was not a physician, he found it difficult to recruit large numbers. So he changed his focus and spent 20 years studying how drugs such as marijuana, tobacco, caffeine and ecstasy affect neurotransmitters.

The increasing struggle for grant money helped lure him to NeuroFocus, a company interested in applying his brain-wave techniques to marketing-effectiveness studies - otherwise known as 'neuromarketing'. "Finding a whole new way to apply brain-wave techniques is an exciting and challenging career move," he says. Indeed, NeuroFocus is expanding to meet demand for neuromarketing expertise.

Bob Knight, a neuroscientist at the University of California, Berkeley, and chief scientific adviser to NeuroFocus, says Polich's work in attention, emotion and memory covers three cardinal facets of neuromarketing. "John is regarded as a meticulous researcher, and as we use science to help grow this industry, he and his impeccable scientific record will help us make sure our research is conducted at the highest level possible," says Knight. Virginia Gewin
NETWORKS \& SUPPORT

\section{EMBL offers lab training in Europe}

Cutting-edge lab training courses are coming to Europe. The European Molecular Biology Laboratory (EMBL) in Heidelberg, Germany, is building a 16,000-square-metre Advanced Training Centre with a 450-person conference room, teaching labs, seminar rooms and an exhibition area.

Due to be completed in September, it will offer conferences and workshops on topics such as identifying protein structures, using biological databases and learning new imaging techniques. Although EMBL emphasizes graduate and postdoc training, the centre will hold conferences and workshops for scientists at all career stages.

EMBL sees this as the European counterpart to Cold Spring Harbor Laboratory (CSHL) in New York, says Matthias Hentze, associate director and coordinator of the centre. "Europe lacks such a centre," he adds. EMBL will supplement, not supplant, the CSHL's renowned programmes, he notes. Many courses and conferences at the CSHL are over-subscribed, or can be offered only intermittently. Some conferences will be available at both facilities, allowing more participants in hot fields. EMBL's central location will also save European scientists travel time and costs, Hentze says.

EMBL has also found a way to help visitors save some money. Leica
Microsystems of Wetzlar, Germany, has committed $€ 50,000$

(US\$63,000) per year, and PerkinElmer of Waltham, Massachusetts, $€ 25,000$ a year, for courses and conferences at the centre for its first three years. This is important because of the research and development funding disparity in the European Union, says Hentze. "There are many places in Europe where funding is very, very small - particularly in eastern

Europe and some countries in the south. We will be able to host conferences at a low fee," he says.

Hentze says that support from the two firms and other anticipated sponsors will keep conference fees to $€ 400-500$ per person and pay entire costs for 200 fellows. "To maximize impact, we will probably use this support for partial and complete 'attendance fellowships' for the needy, rather than spreading it evenly," he says.

The training labs will use equipment from both Leica and Perkin-Elmer. Jörg Fleckenstein, senior manager of resource development at EMBL, says that "they can showpiece their equipment in their training courses, if scientific rationale supports it". He expects that additional sponsors will provide funds for more fellowships. Paul Smaglik

\section{POSTDOC JOURNAL}

\section{Nice day for a white wedding?}

So much for my plan. I had every intention of facing the challenges of the new year with serene Zen-like calm, but I have already crumbled like a stale biscuit. In my defence, the challenges have been stacking up rapidly of late.

We returned home from a New Year camping trip to find my partner, Brett, had been offered a two-year postdoc in Colorado. After the euphoria, we quickly realized that we have only a few months to pack up our life, uproot our three-year-old son, and organize visas and flights for our overseas move.

However, our problems entered a whole new dimension when we discovered that our relationship is not recognized by the United States for visa purposes. For me to accompany Brett to the United States we have to get married - now!

So, in addition to working three separate postdoc contracts, which requires exceptional multitasking skills and many more hours than there are in the week, I now have to organize my nuptials. Although I am overjoyed for Brett, and excited about moving, I can't help but worry about my own career. As I plan to get married and support Brett in his new position, will my career ebb away while his takes off?

Perhaps I should take my own advice, and view this challenge as an opportunity to grow. Maybe I should even think seriously about those other, more child-friendly careers I've heard so much about.

Joanne Isaac is a postdoc in climate-change effects on biodiversity at James Cook University in Townsville, Australia. 